\title{
Giant Cell Arteritis and Polymyalgia Rheumatica: 2016 Update
}

\author{
Gideon Nesher, M.D.* and Gabriel S. Breuer, M.D. \\ Department of Internal Medicine A and the Rheumatology Unit, Shaare-Zedek Medical Center, \\ Jerusalem, Israel
}

\begin{abstract}
ABST RACT
Giant cell arteritis (GCA) and poly myalgia rheumatica (PMR) are both more common among people of North European decent than among Mediterranean people. Women are 2-3 times more commonly affected. Giant cell arteritis and PMR are ex tremely rare before age 50 years. Polymyalgia rheumatica may be "isolated" or associated with GCA. There is increased expression of inflammatory cytokines in temporal arteries of PMR patients, without overt histological evidence of arteritis. One-third of "isolated" PMR patients have vascular uptake in positron emission tomography (PET) scans, suggesting clinically unrecognized, "hidden" GCA. Typical manifestations of GCA are headache, tenderness over temporal arteries, jaw claudication, PMR, acute vision loss, and low-grade fever. Bilateral aching of the shoulders with morning stiffness is typical for PMR. In both conditions sedimentation rate and C-reactive proteinare elev ated, and anemia and thrombocytosis may occur. Color duplex ultrasonography of the temporal arteries may aid in GCA diagnosis. Temporal artery biopsy showing vasculitis, often with giant cells, confirms GCA diagnosis. In cases with negative biopsy one must rely on the clinical presentation and laboratory abnormalities. The diagnosis of PMR is made primarily on clinical grounds. Other conditions that may mimic GCA or PMR must be excluded. Glucocorticoids are the treatment of choice for both conditions. Prompt treatment is crucial in GCA, to prevent irreversible complications of acutevision loss and stroke. Addition oflow-dose aspirin may further prevent these complications. The average duration of treatment is 2-3 years, but some patients require a prolonged course of treatment, and some may develop disease -
\end{abstract}

\footnotetext{
Abbreviations: CRP, C-reactive protein; ESR, elevated sedim entation rate; GCA, g iant cell arteritis; IL, interleukin; INF, in terferon; $\mathrm{PET}$, positron em ission tom ography; $\mathrm{PMR}$, polymyalgia rheumatica; $\mathrm{RS}_{3} \mathrm{PE}$, r elapsing seronegative symmetric sy novitis with pitting edema.
}

Citation: Nesher G, Breuer GS. Giant Cell Arteritis and Polymyalgia Rheumatica: 2016 Update. Rambam Maim onides Med J 2 016;7 (4):eo035. doi:10.5041/RMMJ.10262 Review

Copy right: (C) 2016 Nesher and Br euer. This is a n open-access article. All its content, except where otherwise noted, is distributed under the terms of the Creative Com mons Attribution License (http://creativecom mons.org/licenses/by/3.0), wh ich permits unrestricted $\mathrm{u}$ se, distribution, and reproduction in any m edium, provided the original work is properly cited.

Conflict of interest: No pot ential conflict of in terest relevant to this article was reported.

* Tow hom correspondence sh ould be a ddressed. E-mail: n esherg@szm c.org.il 
related or treatment-related complications. No steroid-sparing agent has been proven to be widely effective thus far, but some promising therapeutic agents are currently being studied.

KEY WORDS: Duplex ultrasonography, glucocorticoids, headache, temporal arteries, temporal artery biopsy, vision loss

\section{INT RODUCTION}

Giant cell arteritis (GCA) is a form of vasculitis that involves the major branches of the aorta with predilection for the vertebral, subclavian, and the ex tracranial branches of the carotid arteries, including the temporal arteries. The aorta and other large and medium-sized arteries may also be involved. Giant cell arteritis develops in individuals older than 50 years of age, and its incidence increases with age. It is considered to be the most common type of vasculitis in this age group.

\section{EPIDEMIOLOGY}

Giant cellarteritis is more common among North Europeans, reaching an annualincidence rate above 20 cases per 100,000 population at risk (age $>50$ ). Itis less common among Mediterranean people. In Israel, the incidence is similar to other Mediterranean countries. ${ }^{1-2}$ The incidence of GCA seems to have been decreasing in the last two decades. ${ }^{1-4}$ Womenare affected 2-3 times more commonly than men.

Poly myalgia rheumatica (PMR) patients share many epidemiologic and pathogenetic features with GCA. Like GCA, PMR develops in patients older than 50 y ears and is more common in women. Similar to GCA, the highest annual incidence rates were observed in Northern Europe, 50-100 per 100,000 population older than 50 years. It is unknown whether PMR is just an expression of an underlying GCA. More likely, it seems that both are a result of an unknown causative factor (or factors), sometimes expressed as PMR, sometimes as GCA, and sometimes as a combination of both conditions. There is a wide range of the reported frequency of PMR in GCA patients (17\%-66\%), and it is estimated that 10\% of "isolated" PMR cases develop GCA symptoms. 5 Clinically, the two conditions may present together but may sometimes be separated by long intervals, and either one may present first.

\section{ET IOLOGY AND PATHOGENESIS}

Etiology is unknown. Several studies implicated infectious agents such as varicella-zoster virus, ${ }^{6}$ but
DNA sequencing oftemporal artery biopsy specimens from GCA cases showed no evidence of previously suspected pathogens.7 The pathogenesis of GCA has been extensively studied but is still not fully understood. It is considered to be a T celldependent disease. Upon dendritic cell activation in the adv entitia by an unknown antigen, $\mathrm{CD}_{4} \mathrm{~T}$ cells are recruited and polarized into Th1 and Th17 lines, producing interferon (IFN) $-\gamma$ and interleukin (IL)17 , respectively, as their main cytokines. The production of cy tokines and activation of macrophages and vascular smooth muscle cells induce sy stemic manifestations, vascular remodeling, and local ischemic manifestations. ${ }^{8-10}$ Macrophages, often forming giant cells, are the major source of cy tokines, growth factors, and metalloproteinases.

There is evidence for increased expression of inflammatory cytokines in the temporal arteries of PMR patients, without overt histological evidence of arteritis. There is local expression of IL-1, IL-2, IL-6, and transforming growth factor (TGF)-beta. ${ }^{11}$ However, in contrast with GCA, T cells producing IFN- $\gamma$ are not attracted to the vessel wall. This lack of IFN$\gamma$ expression in temporal arteries from PMR patients suggests that its production is crucial to the development of overt vasculitis and that a Th1 response may be suppressed in PMR. Using positron emission tomography (PET) scans, increased uptake was documented in thoracic blood vessels in one-third of apparently "isolated" PMR patients, suggestive of inflammation in these vessels, ${ }^{12,13}$ or clinically unrecognized, "hidden" GCA.

\section{CLINICAL FEATURES}

The signs and symptoms of GCA may be classified into four subsets: signs and symptoms of cranial arteritis, ex tracranial arteritis, systemic symptoms, and PMR. Patients may develop any combination of these manifestations. In most instances symptoms develop gradually over a period of several weeks, but onset may sometimes be abrupt.

Headache is a frequent presenting symptom and is ty pically felt over one or both temporal areas. The temporal arteries may seem prominent and tender. 
Generalized or occipital headaches are not uncommon. The headache may be continuous or parox ysmal. Pain in the jaw during mastication, facial pain, and scalp tenderness may also be present. Rarely, GCA may lead to segmental scalpnecrosis or tongue infarction.

Neurologic manifestations are uncommon. Strokes occur in 3\%-7\% of GCA patients. 14 Involvement of the vertebro-basilar system isrelatively more common in GCA-related strokes than in atherosclerotic strokes. ${ }^{4,15}$ It is important to note that strokes may still develop after glucocorticoidtherapy is begun. ${ }^{14,16,17}$ Neuropsychiatric manifestations and peripheral neuropathies are uncommon.

Arteritic anterior ischemic optic neuropathy (AAION), developing in $5 \%-15 \%$ of the patients, is the leading cause of blindness in GCA, sometimes being the presenting manifestation. ${ }^{18,19}$ Arteritic AION is unilateral in most cases, butvisual loss in the other eye may develop; A-AION results from vasculitis of the posterior ciliary arteries, branches of the ophthalmic artery, which supply the optic nerve head and the choroid. Less common causes of visual loss are central retinal artery occlusion, posterior ischemic optic neuropathy, and cortical blindness. Vision loss in GCA is sudden. However, several studies reported that $50 \%$ or more of GCA patients with irreversiblevisual loss had premonitory visual symptoms, such as blurry vision, amaurosis fugax, visual hallucinations, or diplopia. ${ }^{14,18}$ Amaurosis fugax is the most ominous sign of impending visual loss. It should be considered a medical emergency in GCA, as prompt treatment with glucocorticoids and low-dose aspirin may prevent the development of irreversible blindness. Jaw claudication is also associated with increased risk of dev eloping vision loss. ${ }^{20}$ Following vision loss, the visual outcome is poor, even in patients treated with high doses of steroids. Only $5 \%$ had some improvement of both visual acuity and central visual field. ${ }^{21}$

Vestibulo-auditory manifestations are quite common in prospective studies. ${ }^{22}$ Sy mptoms are unilateral or bilateral hearing loss, vertigo, and tinnitus. Onset is usually insidious. A total of $89 \%$ of GCA patients had abnormal vestibular tests, $64 \%$ had subjective hearing impairment, $52 \%$ had vertigo, and $50 \%$ had tinnitus. These were reversible in most cases following steroid therapy.

Signs of occlusive changes in large arteries of the chest and extremities are uncommon. The clinical findings are those of the aortic arch syndrome, indistinguishable from those of Takay asu arteritis: arm claudication, Ray naud's phenomenon, absent or decreased pulses, and bruits over the involved arteries. Clinical signs of aortitis are uncommon. ${ }^{23}$ However, this condition is under-diagnosed, as symptoms are frequently mild, non-specific, and insidious. It is estimated that GCA patients have a 2fold increased risk of aortic aneurysm. ${ }^{24}$ Sy mptoms suggestive of involvement of the coronary, mesenteric, and lower extremity arteries are rare.

Sy stemic manifestations (fever, malaise, fatigue, anorexia, and weight loss) occur quite often, in $30 \%-60 \%$ of the patients. In some cases, these may be the only symptoms of GCA. Fever is typically lowgrade, and temperatures rarely exceed $39^{\circ} \mathrm{C}$. The ty pical symptoms of PMR are aching of the shoulder girdle and neck, associated with morning stiffness. The hip girdle may also be involved. These sy mptoms are probably related to inflammation of the glenohumeral and hip joints, and the subacromial, subdeltoid, and trochanteric bursae. One-third of PMR patients have systemic manifestations such as low-grade fever, malaise, and anorexia, butthese are milder than in GCA. A subgroup of PMR patients presents with arthralgia or synovitis of peripheral joints, predominantly hands and knees. ${ }^{25}$ Some present with symmetric synovitis with pitting edema, compatible with the relapsing seronegative symmetric synovitis with pitting edema $\left(\mathrm{RS}_{3} \mathrm{PE}\right)$ syndrome. ${ }^{26}$ It is difficult at times to distinguish between these patients and patients with elderly onset rheumatoid arthritis (RA). 27

\section{DIAGNOSIS}

The diagnosis of PMR and GCA is made primarily on clinical grounds and is bolstered by laboratory evidence of an acute-phase reaction, most commonly elevated levels of erythrocyte sedimentation rate (ESR) and C-reactive protein (CRP), as well as anemia of inflammation and thrombocytosis. Various conditions can mimic GCA and PMR, 28 and should be considered in the differential diagnosis (Table 1). A small group of patients may present with typical features of the disease but without elevation of the ESR. 29

The only test that confirms the diagnosis of GCA is a temporal artery biopsy, showing vasculitis with mononuclear cell infiltrates, often with giant cells (Figure 1). Giant cell arteritis affects the vessels in segments, therefore areas of vasculitis may be missed and the histological examination is normal 
Giant Cell Arteritis and Polymyalgia Rheumatica

Table 1. Conditions That Should Be Considered in the Differential Diagnosis of PMR and GCA.

\begin{tabular}{ll|}
\hline \multicolumn{1}{|c}{ Polymyalgia Rheumatica (PMA) } & \multicolumn{1}{c|}{ Giant Cell Arteritis (GCA) } \\
\hline Elderly-onset rheumatoid arthritis & Sinusitis \\
Fibromyalgia & Dental and temporo-mandibular conditions \\
Shoulder bursitis/tendinitis & Non-arteritic anterior ischemic optic neuropathy \\
Cervical spondylosis & Subacute thyroiditis \\
Ankylosing spondylitis/sacroileitis (early stages) & Chronic infections (infective endocarditis, etc.) \\
Hypothyroidism & Trigeminal neuralgia \\
Viral infections, chronic infections & Malignancy \\
Polymyositis & Atherosclerotic cardiovascular disease \\
Malignancy & \\
Amyloidosis & \\
\hline
\end{tabular}

in $10 \%-30 \%$ of GCA patients ("biopsy-negative GCA").30 A temporal artery biopsy length largerthan $5 \mathrm{~mm}$ is associated with increasing diagnostic yield, but the optimal length is probably higher. ${ }^{31}$ Biopsying temporal arteries on both sides may also increase the diagnostic yield. ${ }^{2}$ It is preferable to perform the biopsy as soon as possible, but the specimen may show signs of arteritis even after $2-4$ weeks of treatment. 33

Some imaging modalities may aid in the diagnosis of GCA. Among those, color duplex ultrasonography of the temporal arteries is more commonly used. A peri-luminal hypo-echoic halo (Figure 2), probably representing vessel-wall edema, was suggested to be highly sensitive and specific for GCA.34 However, results are operator-dependent and vary

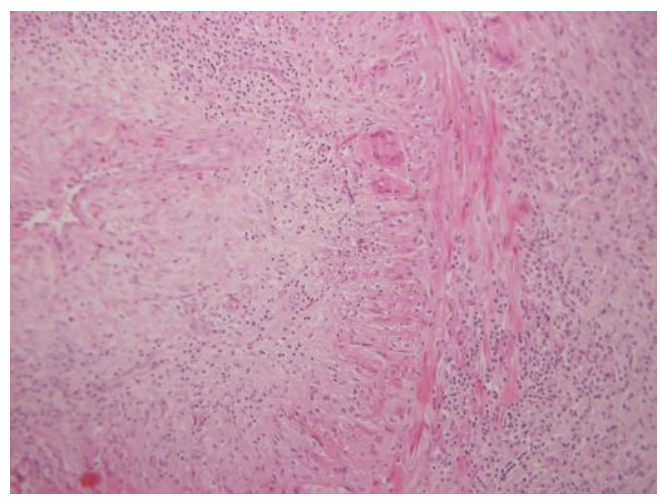

Figure 1. Temporal Artery of a Patient with Giant Cell Arteritis.

Image shows intense trans-mural inflammatory infiltrate, multi-nucleated giant cells, intimal hyperplasia, and severe narrowing of the lumen. considerably among studies examining the diagnostic value of color duplex ultrasonography. 35

High-resolution contrast-enhanced magnetic resonance imaging (MRI) of the temporal arteries also enables evaluation of possible inflammation of the vessel wall. Preliminary results show high sensitivity of this imaging modality, ${ }^{36}$ with diagnostic y ield comparable to color duplex ultrasonography. 37 Angiography of the aortic arch and its branches may serve to diagnose large-vessel involv ement. Noninvasive modalities, such as PET scans, may also be employed to detect large-vessel involvement in the chest, neck, and abdomen. ${ }^{8}$ The specificity of PET for GCA diagnosis is considered to be very high ( $100 \%$ ), but sensitivity is lower ( $66 \%)$. It may also serve to evaluate response to treatment and GCA disease exacerbations.

Serological tests were not helpful in diagnosing GCA. Autoantibodies were not consistently found in GCA, although plasma cells can be found in the adventitia in $7 \%-24 \%$ of temporal artery biopsies from patients with GCA. 39 The ex ception was antiphospholipid antibodies (APLA), which were found in 30\%-80\% of GCA cases. $40-43$ Antibodies to lamin $\mathrm{C}$ were found in one-third of GCA patients and in none of the controls. 44 Autoantibodies to a human ferritin peptide (the heavy chain N-terminal) were found in $92 \%$ of 36 patients with GCA and/or PMR.45,46 In addition, 89\% had antibodies to bacterial ferritin peptide of Staphylococcus epidermidis. Anti-ferritin antibodies were found in much lower rates in disease controls. Following these reports, another group of researchers reported their experience with anti-ferritin antibodies in GCA. 47 They found a test sensitivity of $82 \%$ in biopsy-positive 

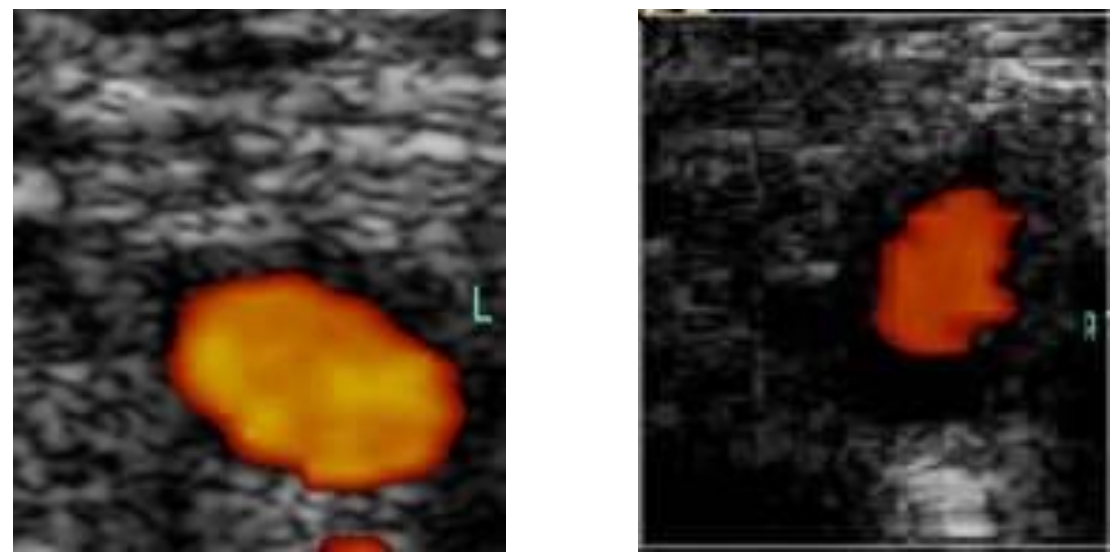

Figure 2. Ultrasonography of Temporal Artery of a Patient with Giant Cell Arteritis.

Left: Normal duplex ultrasonography of the left temporal artery of a patient with giant cell arteritis. Right: Duplex ultrasonography of the right temporal artery of the same patient, showing peri-luminal dark halo.

GCA patients. Anti-ferritin antibodies were foundin $34 \%$ of disease controls and $3 \%$ of healthy controls. Upon further testing, these antibodies may prove useful as a diagnostic marker of GCA.

There are no independentvalidating criteria to determine whether GCA is present when a temporal artery biopsy is negative. The American College of Rheumatology (ACR) criteria for classification of GCA 48 may assist in GCA diagnosis (Table 2). However, those classification criteria serve mainly to classify GCA within the group of vasculitides. Their purpose was to differentiate GCA from other types of vasculitis, and not to differentiate GCA fromother disease conditions. It is highly important to realize

Table 2. The American College of Rheumatology 1990 GCA Classification Criteria.

\section{GCA Classific ation Criteria}

(1) Age at onset $\geq 50$ years

(2) A new headache

(3) Temporal artery abnormality such as tenderness to palpation or decreased pulsation

(4) Erythrocyte sedimentation rate $\geq 50 \mathrm{~mm} / \mathrm{h}$

(5) Abnormal artery biopsy showing vasculitis with mononuclear cell or granulomatous inflammation, usually with giant cells

At least three of the five parameters must be present, which yields a sensitivity of $93 \%$ and a specificity of $91 \%$, in relation to controls with other vasculitides. that these are not diagnostic criteria. Their validity as criteria for GCA diagnosis has been questioned. 49 Such classification criteria do not work well when used for diagnosing individual cases. 50 The final diagnosis should be based on all clinical, laboratory, imaging, and histological findings.

The diagnosis of PMR is made primarily on clinical grounds and laboratory evidence of an acute phase reaction. 28,51 There is no single diagnostic test for PMR, but sets of diagnostic and classification criteria have been suggested by several groups of investigators. Recently, provisional classification criteria (Table 3) were published as a collaborative initiative of the European League Against Rheumatism (EULAR) and the ACR. $5^{2}$ With these criteria, the required score has $68 \%$ sensitivity and $78 \%$ specificity for discriminating PMR from comparison patients. The positive predictivevalue is $69 \%$, and the negative predictive value $77 \%$. These new classification criteria need further validation.

There is a wide range of the reported frequency of GCA in patients presenting with PMR. One diagnostic option is routinely to biopsy the temporal arteries in all PMR patients. In this approach, the chance of missing GCA is small, but the frequency of positive biopsies is very low. 53 The more accepted strategy is to biopsy only those patients who have symptoms suggestive of GCA. With this approach the results are likely to vary according to the expertise of the examining physician. 54 There have been some attempts to develop guidelines for performing temporal artery biopsy in patients with PMR.55,56 Patients with PMR who were younger than 70 years 
Giant Cell Arteritis and Polymyalgia Rheumatica

Table 3. The 2012 Provisional PMR Classification Criteria (A Collaborative Initiative of the European League Against Rheumatism and the American College of Rheumatology).

\begin{tabular}{l|c|}
\hline \multicolumn{1}{|c}{ PMR Classification criteria } & Points \\
\hline Clinical Criteria & 2 \\
Morning stiffness duration $>45 \mathrm{~min}$ & 1 \\
Hip pain or limited range of motion & 2 \\
Absence of rheumatoid factor or anti-citrullinated peptide antibodies & 1 \\
Absence of other joint pain & 1 \\
Ultrasound Criteria & 1 \\
At least one shoulder with subdeltoid bursitis and/or biceps tenosynovitis and/or \\
glenohumeral synovitis (either posterior or axillary), and at least one hip with synovitis \\
and/or trochanteric bursitis \\
Both shoulders with subdeltoid bursitis, biceps tenosynovitis, or glenohumeral synovitis
\end{tabular}

Required criteria for all cases: (1) age 50 or older; (2) bilateral shoulder pain; (3) elevated ESR and/or CRP.

With only clinic al criteria, a score of $>4$ is required. With combined clinic al and ultrasound criteria, a score of $>5$ is required. The required score has $68 \%$ sensitivity and $78 \%$ specificity for discriminating PMR from comparison patients. The positive predic tive value is $69 \%$, and the negative predictive value $77 \%$.

of age, and with no features of cranial vasculitis (such as a new headache, jaw claudication, abnormalities of the temporalarteries on examination, or amaurosis fugax), were unlikely to have a positive biopsy. Older patients with cranial vasculitis findings were more likely to have a positive biopsy. Severe degrees of anemia and thrombocy tosis are suggestive of GCA in patients presenting with PMR sy mptoms. Also, poor clinical response to low-dose prednisone (15-20 $\mathrm{mg} /$ day) and persistent abnormalities in laboratory parameters of inflammation are also suggestive of GCA in patients presenting with "isolated" PMR. In such cases ultrasonography and biopsy of the temporal arteries should be performed to rule out GCA.

\section{T HERAPY, DISEASE COURSE, AND PROGNOSIS}

Glucocorticoids are the mainstay of treatment for both PMR and GCA.57,58 In PMR, the starting recommended dose is $15-20 \mathrm{mg} /$ day. Symptoms ty pically begin to abate within $1-3$ days, but a few patients may still have some pain and stiffness several weeks after initiation of treatment. After 2-4 weeks, following improvement of the clinical features of the disease together with normalization of the inflammatory markers, the dose of gluco corticoids can be tapered gradually. Relapses occur in about one-half of the patients, with response to increasing the dose for several weeks. Tapering of the dose should then be resumed.

The duration of treatment for PMR v aries from 6 months to several years, and the majority of patients develop steroid-related side effects. Methotrex ate was evaluated as a steroid-sparing agent withmixed results. Addition of methotrexate can be considered in relapsing disease, in patients who are regarded at high risk for developing adverse events, or in patients experiencing steroid-related adverse effects. 59 Poly myalgia rheumatica is thought to have a benign course, with a variable degree of treatment-related morbidity.

In GCA, the initial dose is $40-60 \mathrm{mg} /$ day for most cases. 58 Patients with vascular complications such as vision loss (transient or permanent), diplopia, transient ischemic attacks, or stroke may be treated initially with higher doses such as 500$1,000 \mathrm{mg} /$ day of intravenous methylprednisolone for three consecutive days, in an attempt to prevent additional ischemic complications.

Rapid improvement of all clinical manifestations following treatment initiation is characteristic. Prompt treatment is crucial in GCA to prevent irreversible ischemic complications, such as acute vision loss or stroke. Thus therapy should not be delayed pending temporal artery biopsy, which should be performed as soon as possible. 
After 2-4 weeks, following improvement of the clinical features of the disease together with normalization of ESR and CRP, the dose of glucocorticoids can be tapered, with close monitoring for recurrence of symptoms. During follow-up, levels of ESR and CRP do not alway s correlate with disease activity. Elevation of these acute-phase reactants while the patient is asy mptomatic is not an absolute indication to increase the dose of prednisone. In such cases, it is preferable to slow the rate of dosage tapering and continue to watch closely for recurrence of symptoms. On the other hand, the dose should be increased if symptoms recur, even when the ESR or CRP remain within the normal range. The average duration of treatment is $2-3$ years. Relapses are experienced by about half of GCA patients. Most relapses are mild, but some patients may still develop vision loss or stroke during the course of corticosteroid treatment or afterdiscontinuation of therapy. Addition of low-dose aspirin (100 $\mathrm{mg} / \mathrm{d}$ ) has been shown to decrease the rate of vision loss and stroke during the course of the disease, probably mediated by its anti-platelet effect. ${ }^{60,61}$

Some GCA patients with thoracic or peripheral vascular involvement may benefit from surgical interventions, such as balloon angioplasty or stents for vascular stenosis, and prostheses for aortic aneury sms. Aortic complications may occurearly or late in the course of GCA, sometimes after the completion of drug treatment. In mostcases, aortic structural damage was not associated with persistence of detectable disease activity ${ }^{62}$ Indications for regular imaging of the aorta in GCA have not yet been determined. 63

Individual cases vary greatly, therefore theexact doses and the duration of treatment should be adjusted to the needs of the individual patient, considering both disease manifestations and glucocorticoid adverse effects. Patients with strong initial systemic inflammatory response tend to have a prolonged disease course with more flares, requiring higher cumulative steroid doses. 64 No steroidsparing agent has been proven to be highly effective thus far, but a few reports suggest somebeneficial effects of methotrexate and cyclophosphamide. 65,66 These medications may be prescribed in certain situations, such as resistant cases, or in cases at high risk of glucocorticoid-related side effects. Recently, several case studies reported beneficial effects of tocilizumab, an IL-6 receptor antagonist. A randomized prospective study of 30 patients reported recently that patients given a combination of tocili- zumab and prednisolone were able to discontinue prednisolone 12 weeks earlier than patients given prednisolone only. 67

It is apparent that GCA may result in fatal complications. The major causes of mortality have been vascular: stroke, coronary artery events, rupture of thoracic aortic aneurysms, and aortic dissection. In addition, there is increased occurrence of severe infections. ${ }^{68}$ The impact on the overall prognosis is controversial.2,3,68-70 So me epidemiologic studies reported increased mortality, mostly during the first year after diagnosis, while others found that the overall life expectancy among GCA patients was essentially identical to that of the general population.

\section{CONCLUSIONS}

Giant cell arteritis is considered to be the most common type of primary vaculitis in the elderly.It may cause severe morbidity such as acute loss of vision and stroke, but prompt diagnosis and proper treatment would prevent such ischemic episodes in most cases. It is unknown whether PMR is just an expression of an underlying GCA. More likely, it seems that both are a result of an unknown causative factor (or factors), sometimes expressedas PMR, sometimes as GCA, and sometimes as a combination. Clinically, the two conditions may present together but may sometimes be separated by long intervals, and either one may present first. Treatment-related morbidity is a concern in both conditions, but several promising therapeutic agents are currently being studied.

\section{REFERENCES}

1. Nesher G, Ben-Chetrit E, MazalB, Breuer GS. The incidence of primary systemic vasculitis in Jeru salem : a 20 -year hospital-based retrospective study. J Rheumatol 2016;43:1072-7. Full Text

2. Catanoso M, Macchioni P, Boiardi L, et al. Incidence, prev alence and su rvival of biopsy -proven giant cell arteritis in Northern Italy during a 26-year period. Arthritis Care Res (Hoboken) 2016 May 23. [Epub ahead of print].

3. Moham mad AJ, Nilsson JA, Jacobsson LT, Merkel PA, Turesson C. Incidence and mortality rates of biopsy -proven giant cell arteritis in Southern Sweden. Ann Rheum Dis 2015;74:993-7. Full Text

4. Salvarani C, Crowson CS, O'Fallon WM, Hunder GG, GabrielSE. Reappraisal of the epidemiology of giant cell arteritis in Olmsted County, Minnesota, ov er a 
fifty-year period. Arthritis Rheum 2004;51:264-8. Full Text

5. NarvaezJ, Estrada P, Lopez-Vives L, et al.Prevalence of ischem ic complication s in patients with giant cell arterirtis presenting with apparently isolated poly myalgia rheumatica. Semin Arthritis Rheum 2015;45: 328-33. Full Text

6. Nagel MA, White T, Khmeleva N, et al. Analy sis of $\mathrm{v}$ aricella-zoster virus in tem poral arteries biopsy positiv eand negative for giant cell arteritis. JAMA Neurol 2015;7 2:1281-7. Full Text

7. Bhatt AS, Manzo VE, Pedamallu CS, et al. In search of a candidate pathogen for giant cell arteritis: sequencing-based characterization of the giant cell arteritis microbiome. Arthritis Rheumatol 2014;66: 1939-44. Full Text

8. Wey andCM, Goronzy JJ. Im munem echanism s in medium and large vessel vasculitis. Nat Rev Rheumatol 2013;9:731-40. Full Text

9. Ly KH, Regent A, Tamby MC, Mouthon L Pathogenesis of giant cell arteritis: more than just an inflammatory condition? Autoimmun Rev 2010;9;635-45. Full Text

10. Borchers AT, Gershwin ME. Giant cell arteritis: a rev iew of classification, pathophy siology, geoepidemiology and treatment. Autoimmun Rev 2012;11: A544-5. Full Text

11. Wey andCM, Goronzy JJ. Medium andlarge v essel v asculitis. N Eng J Med 2 003;349:160-9. Full Text

12. Moosig F, Czech N, Mehl C, et al. Correlation between 18-fluorodeoxy glucose a ccumulation in largevessels and serological markers of inflam mation in poly myalgia rheumatica: a quantitative PET study. Ann Rheum Dis 2004;63:870-3. Full Text

13. Blockm ans D, De Ceuninck I, Vanderschueren S, Knockaert D, Mortelmans L, Bobbaers H. Repetitive 18-fluorodeoxy glucose positron emission tomography in isolated polymyalgia rheumatic: a prospective study in 35 patients. Rheumatology (Oxford) 2007; 46:672-7. Full Text

14. Nesher G, Berkun Y, Mates M, et al. Risk factors for cranial ischemic complications in giant cell arteritis. Medicine (Baltimore) 2004;83:1 14-22. Full Text

15. Ruegg S, Engelter S, Jeanneret C, et al. Bilateral ver tebral artery occlusion resulting from giant cell arteritis: report of 3 cases and review of theliterature. Medicine (Baltim ore) 2003;82:1-12. Full Text

16. González-Gay MA, Blanco R, Rodriguez-ValverdeV, Martinez-Taboada VM, Delgado-Rodriguez M, Figueroa M. Permanent visual loss and cerebro$\mathrm{v}$ ascular accidents in giant cell arteritis: predictor $\mathrm{s}$ and respon se to treatment.Arthritis Rheum 1998;41: 1497-504. Full Text

17. Staunton H, Stafford F, Leader M, O'Riordain D. Deterior ation of giant cell arteritis with corticosteroid therapy. Arch Neurol 2000;57:581-4. Full Text

18. González-Gay MA, García-Por rua C, Lior ca J, et al. Visual manifestations of giant cell arteritis. Medicine (Baltim ore) 2000;79:283-92. Full Text

19. Waqar S, Salman R, Sleep T. Ophthalmic manifestation s of giant cell arteritis. Br J Hosp Med 2011;72: 26-30. Full Text

20. Singh AG, Kermani TA, Krowson CS, Wey and CM, Matteson EL, Warrington KJ. Visual manifestations in giant cell arteritis: trend ov er 5 decades in a population-based cohort. J Rheumatol 2015;42:30915. Full Text

21. Danesh-Meyer H, Savino PJ, Gamble GD. Poor prognosis of $v$ isual ou tcome after visual loss from giant cell arteritis. Ophthalmology 2005;112:1098103. Full Text

22. Am or-dor ado JC, Llor ca J, Garcia-Por rua C, Costa C, Perez-Fernandez N, Gonzalez-Gay MA. Audiov estibular manifestations in giant cell arteritis: a prospective study. Medicine(Baltimore) 2003;82:13-26. Full $\underline{\text { Text }}$

23. Nuenningh of DM, Hunder GG, Christianson TJ, McClelland RL, Matteson EL. Incidence and predictor s of large-artery com plication (aortic aneurysm, a ortic dissection, and/or large-artery stenosis) in patients with giant cell arteritis: a population-based study over 50years. Arthritis Rheum 2003;48:352231. Full Text

24. Robson JC, Kir an A, MaskellJ, et al. The relative risk of a ortic aneurysm in patients with giant cell arteritis com pared with the general population in the UK. Ann Rheum Dis 2015;74:129-35. Full Text

25. Gran JT, Myklebust G. The incidence and clinical characteristics of peripheral arthritis in poly myalgia rheumatica and temporal arteritis: a prospective study of 231 cases. Rheumatology (Oxford) 2000;39: 283-7. Full Text

26. Oliv ieri I, Salvarani C, Cantini F. Remitting distal extremity swelling with pitting edema: a distinct syndrom e or a clinical feature of different inflammatory rheumatic disease?J Rheumatol 1997;24:249-52.

27. Pease CT, Haugeberg G, Morgan AW, Montague B, Hensor EM, Bhakta BB. Diagnosing late-onset rheumatoid arthritis, polymyalgia rheumatica, and tem poral arteritis in patients presenting with poly myalgic symptoms. A prospective longterm study. J Rheumatol 2005;32:1043-6. 
28. González-Gay MA, García-Por rua C, Salvarani C, Oliv ieri I, Hunder GG. Poly myalgia manifestations in differ ent conditions mimicking polymyalgia rheu matica. Clin Exp Rheumatol 2000;18:755-9.

29. Salvarani C, Hunder GG. Giant cell arterit is withlow ery throcyte sedimentation rate: frequency of occurrence in a population-based study. Arthritis Rheum 2001;45:140-5. Full Text

30. Breuer GS, Nesher R, Nesher G. Negative temporal artery biopsies: eventual diagnoses and features of patients with biopsy -negativ e giant cell arteritis compared to patients without arteritis. Clin Exp Rheumatol 2008;26:1103-6.

31. Breuer GS, Nesher R, Nesher G. Effect of biopsy length on the rate of positive temporal artery biopsies. Clin Exp Rheumatol 2009;27(1 suppl $52): S 10-13$.

32. Breuer GS, Nesher G, Nesher R. Rate of discor dant findings in bilateral temporal artery biopsy to diagnose giant cell arteritis. J Rheumatol 2009;36:794-6. Full Text

33. Narvaez J, Bernard B, Roig-Vilaseca D, et al. Influence of previou s corticosteroid therapy on temporal artery biopsy y ield in giant cell arteritis. Semin Arthritis Rheum 2007;37:13-19. Full Text

34. Schmidt WA, Kraft HE, Vorpahl K, Volker L, Grom nica-Ihle EJ. Color duplex ultrasonog raphy in the diagnosis of tem poral arteritis. N Engl J Med 1997;337:1336-42. Full Text

35. Maldini C, Depinay-Dhellem mes C, Tra TT, et al. Limited value of temporal artery ultra sonography examinations for diagnosis of giant cell arteritis: analysis of 77 subjects. J Rheumatol 2010;37;232630. Full Text

36. Klink T, Geiger J, Both M, et al. Giant cell arteritis: diagnosticaccuracy of MR imaging of superficial cranial arteries in initial diagnosis - results from a multicenter trial. Radiology $2014 ; 273: 844-52$. Full $\underline{\text { Text }}$

37. Bley TA, Reinhard M, Hauenstein C, et al. Comparison of duplex sonography and high-resolution magnetic reson ance imaging in the diag nosis of giant cell (tem poral) arteritis. Arthritis Rheum 2008;58:25748. Full Text

38. Blockm ans D. PET in v asculitis. Ann N Y Acad Sci 2011;1228:64-70. Full Text

39. Chatelain D, Duhaut P, Loire R, et al. Small-v essel $\mathrm{v}$ a sculitis surrou nding an u ninflamed temporal artery: a new diagnostic criterion for poly myalgia rheumatica? Arthritis Rheum 2008;58:2565-73. Full Text

40. Chakravarty K, Pountain G, Merry P, Byron M, Hazleman B, Scott DG. Alongitudinal study of anticardio- lipin antibody in polymyalgia rheumatica and giant cell arteritis. J Rheumatol 1995;22:1694-7.

41. Manna R, Latteri M, Cristiano G, Todaro L, Scu deri F, Gasbarrini G. Anticardiolipin antibodies in giant cell arteritis and polymyalgia rheumatica: a study of 40 cases. Br J Rheumatol 1998;37:208-10. Full Text

42. Liozon E, Roblot P, Paire D, et al. Anticardiolipin antibody levels predict flares and relapses in patients with giant-cell (temporal) arteritis. A longitudinal study of 58 biopsy -proven cases. Rheumatology (Oxford) 2000;39:1089-94. Full Text

43. Espinosa G, Tàssies D, Font J, et al. Antiphospholipid antibodies and thrombophilic factors in giant cell arteritis. Semin Arthritis Rheum 2001;31:12-20. Full $\underline{\text { Text }}$

44. Schmits R, Kubuschok B, Schuster S, Preuss KD, Pfreundschuh M. Analy sis of the B cell repertoire against autoa ntigens in patients with giant cell arteritis and poly myalgia rheumatic. Clin Exp Im m unol 2002;127:379-85. Full Text

45. Baerlecken NT, Linnemann A, Gross WL, et al. Association of ferritin a utoantibodies with giant cell arteritis/polymyalgia rheumatica. Ann Rheum Dis 2012;71:943-7. Full Text

46. Große K, Schmidt RE, Witte T, Baerlecken NT. Epitope mapping of antibodies a gain st ferritin heavy chain in giant cell arteritis and poly myalgia rheumatica. Scand J Rheumatol 2013;42:215-19. Full Text

47. Régent A, Ly KH, Blet A, et al. Contribution of antifer ritin a ntibodies to diagnosis of giant cell arteritis. Ann Rheum Dis 2013;7 2:1269-70. Full Text

48. Hunder GG, Bloch DA, Michel BA, et al. The Am erican College of Rh eu matology 1990 criteria for the classification of giant cell arteritis. Arthritis Rheum 1990;33:1122-8. Full Text

49. Murchison AP, Gilbert ME, Bilyk JR, et al. Validity of the American College of Rheu matology criteria for the diagnosis of giant cell arteritis. Am J Ophthalmol 2012;154:722-9. Full Text

50. Hunder GG. The use and misuse of classification and diagnostic criteria for complex disease. Ann Intern Med 1998;1 29:417-18. Full Text

51. Caporali R, Montecucco C, Epis O, Bobbio-Pallavicini F, Maio T, Cimmino MA. Presenting features of poly myalgia rheumatica (PMR) and r heumatoid arthritis with PMR-like onset: a prospective study. Ann Rheum Dis 2001;60:1021-4. Full Text

52. Dasgupta B, Cimmino MA, Maradit-Kremers H, et al. 2012 provisional classification criteria for polymyalgia rheumatica: a European League Against Rheumatism/American College of Rh eumatology collaborative initiative. Ann Rheum Dis 2012;71:484-92. Full Text 
53. Schmidt WA, Gromnica-Ihle EJ. Incidence of tem por al arteritis in patients with poly myalgia rheumatica: a prospective study using color Doppler ultrasonography of the tempor al arteries. Rheumatology (Oxford) 2002;20:309-18. Full Text

54. Hunder GG. Giant cell arteritis in poly my algia rheumatica. Am J Med 1997;102:514-16. Full Text

55. Gabriel SE, O'Fallon WM, Achka AA, Lie JT, Hunder GG. The u se of clinical characteristics to predict the results of temporal artery biopsy among patients with su spected giant cell arteritis. J Rheumatol 1995;22: 93-6.

56. Rodriguez-Valverde V, Sarabia JM, González-Gay MA, Figueroa M, Armona, J, Blanco R. Risk factor s and predictive models of giant cell arteritis in poly myalgia rheumatica.Am J Med 1997;102:331-6. Full $\underline{\text { Text }}$

57. Kermani TA, Warrington KJ. Polymyalgia rheumatica. Lancet 2013;381:63-72. Full Text

58. Dasgupta B, Borg FA, Hassan N, et al. BSR and BHPR guidelines for the management of giant cell arteritis. Rheu m atology (Oxford) 2010;49:1594-7. Full Text

59. Cim mino MA, Salvarani C, Macchioni P, et al. Longterm follow-up of poly myalgia rheumatica patients treated with m ethotrexate and steroids. Clin Exp Rheumatol 2008;26:395-400.

6o. Nesher G, Berkun Y, Mates M, Baras M, Rubinow A, Sonnenblick M. Low-dose aspirin and prevention of cranial ischemic complications in giant cell arteritis. Arthritis Rheum 2004;50:1332-7. Full Text

61. Martinez-Taboada VM, Lopez-Hoy os M, Narvaez J, Mu noz-Cacho P. Effect of a ntiplatelet/anticoagulant therapy on severe ischemic complication s in patients with giant cell arteritis: a cumulative meta-a nalysis. Autoimmun Rev 2014;13:788-94. Full Text

62. Garcia-Martinez A, Arguis P, Prieto-Gonzalez S, et al. Prospective long term follow-up of a cohort of patients with giant cell arteritis screened for a ortic structural damage(aneurysm or dilatation). Ann Rheum Dis 2014;73:1826-32. Full Text

63. Mackie SL, Hensor EM, Morgan AW, Pease CT. Should Isend my patient with previous giant cell arteritis for imaging of the thoracic aorta? A sy stematic literature review and m eta-analy sis. Ann Rheum Dis 2014;73:143-8. Full Text

64. Nesher G, Nesher R, Mates M, Sonnenblick M, Breu er GS. Giant cell arteritis: intensity of the initial sy stemic inflammatory response and thecourse of the disease. Clin Exp Rheumatol 2008;26(suppl 49): S30-4. Full Text

65. Mahr AD, Jover JA, Spiera RF, et al. Adjunctive m eth otrexate for treatment of giant cell arteritis: an individual patient data meta-analy sis. Arthritis Rheum 2007;56:2789-97. Full Text

66. Quartuccio L, Maset M, De Maglio G, et al. Role of or al cyclophosphamide in thetreatment of giant cell arteritis. Rheumatology (Oxford) 2012;51:1677-86. Full Text

67. Villiger PM, Adler S, Kuchen S, et al. Tocilizumab for induction and maintenance of remission in giant cell arteritis: a phase 2, randomized, double-blind, placebo-controlled trial. Lancet 2 016;387:1921-7. Full Text

68. Schmidt J, Smail A, Roche B, et al. Incidence of severe infection s and infection-related mor tality during the cour se of giant cell arteritis: a multicenter, prospective, double-cohort study. Arthritis Rheumatol 201 6;68: 1477-82. Full Text

69. Nesher G, Sonnenblick M, Friedlander Y. Analysis of steroid related complications and mortality in tem poral arteritis: a 15 -year survey of 43 patients. $J$ Rheumatol 1994;21:1283-6.

70. Baslund B, Helleberg M, Faurschou M, Obel N. Mortality in patients with giant cell arteritis. Rheu m atology (Oxford) 2 015;54:139-43. Full Text 